\title{
ASIMILASI ARSITEKTUR DI LASEM JAWA TENGAH
}

\author{
RR. Sophia Ratna Haryati \\ Program Studi Arsitektur, Fakultas Sains dan Teknologi, \\ Universitas Amikom Yogyakarta. \\ rr_sophia_rh@amikom.ac.id
}

\begin{abstract}
The process of cultural acculturation and archipelago architecture began since the entry of traders who bring value and cultural elements which then synergize with local culture. From history, we can see, many forms of archipelago architecture has since opened up to the influence of the outer culture that comes in. The cities of Lasem, Tuban and Gresik in the North Coast in the Eastern part of Java Island are the cities that became the starting point of entry of foreign traders. So do not be surprised if the shape of the architecture of the North Coast area in the eastern part of Java is heavily influenced by Chinese, Arabic, and Colonial cultural values. This is reinforced by historical data about the entry of 13th century Chinese culture, Arabic in the fifteenth century and the Dutch (VOC) in the 17th century. The entry of Chinese, Arab, and Dutch Culture to Indonesia in the glorious period of the Majapahit Kingdom gave a touch of change and continuity in various cultural activities. Traces of relations between these cultures that eventually create a form of acculturation of architecture that appears from the shape and meaning of existing buildings in the area of the North Coast in the Eastern part of Java Island. From the exploration process conducted by phenomenological approach that focuses on the process of acculturation of architecture, will be able to prove that Lasem Region is an expression of acculturation between Chinese culture, Middle East, Colonial, and Java through its concepts.
\end{abstract}

Key words: semiotics of space, traditional settlements Baluwarti, heritage areas

\section{Pendahuluan}

Kebudayaan merupakan satu integrasi yang bersumber pada sifat adaptif. Fakta yang menunjukkan bahwa kebudayaan-kebudayaan cenderung berintegrasi yaitu banyaknya kebudayaan yang unsur-unsurnya selaras satu dengan lainnya. Sejak masa klasik yang mencapai titik puncaknya pada zaman Majapahit, Nusantara telah dihuni berbagai etnis dan ras yang saling berinteraksi dengan membawa budayanya sendiri. Kota-kota pantai yang terdapat di berbagai pulaupulau di Indonesia, sejak abad ke-13 yang merupakan jalur perdagangan internasional di masa lampau, telah menempati kedudukan yang penting dalam dinamika kebudayaan yang terjadi peleburan komunitas sosial dan kultural.

Kota-kota pantai di Indonesia memiliki tipologi kota yang multikultur, yang terbentuk dan berkembang dengan masyarakat yang multi-etnis serta membentuk struktur yang heterogen dengan budaya baru melalui proses akulturasi.

Di antara kota-kota pantai tersebut adalah Kota Lasem yang pada zaman dahulu telah dikenal sebagai kota pelabuhan yang banyak disinggahi kapal-kapal pedagang karena letaknya yang dilewati oleh jalur pantai utara dengan jalur perdagangan penting dunia di Sungai Babagan (Graaf, 1997). Seperti terlihat pada gambar 1, Kecamatan Lasem ini merupakan salah satu kecamatan di pesisir pantai Laut Jawa di Kabupaten Rembang, berjarak lebih kurang $12 \mathrm{~km}$ ke arah timur dari ibukota Kabupaten Rembang, dengan batas-batas wilayah meliputi:

a. Utara berbatasan dengan Laut Jawa,

b. Timur berbatasan dengan Kecamatan Sluke, c. Selatan berbatasan dengan Kecamatan Pancur,

d. Barat berbatasan dengan Kecamatan Rembang.

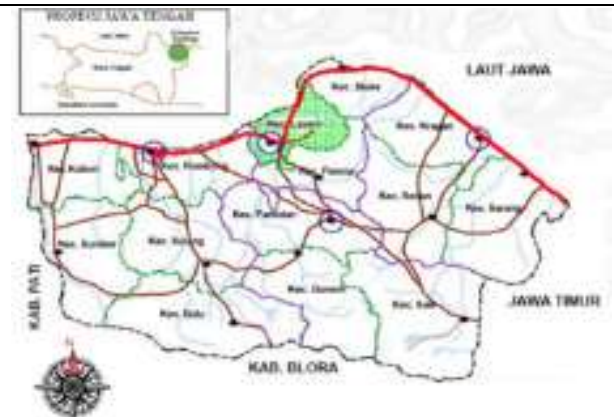

Gambar 1. Peta Kabupaten Rembang

Sumber: lasemheritagecity.file.wordpress.com

Seperti terlihat pada gambar 2, Kecamatan Lasem mempunyai luas wilayah mulai dari pesisir Laut Jawa hingga ke selatan. Di sebelah timur terdapat Gunung Lasem. Wilayahnya seluas 4.504 ha di mana 505 ha digunakan sebagai pemukiman, 281 ha sebagai lahan tambak, 624 ha sebagai hutan milik negara.

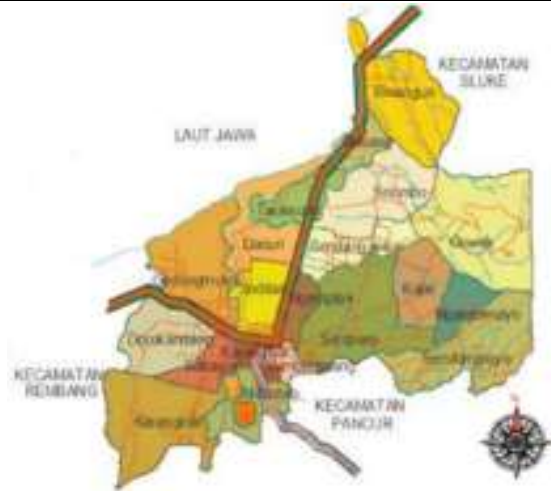

Gambar 2. Peta Kecamatan Lasem

Sumber: lasemheritagecity.file.wordpress.com 
Kecamatan Lasem merupakan kawasan prioritas yang berperan sebagai kawasan yang menunjang kegiatan sektor strategis baik yang berskala lokal maupun regional, seperti perdagangan, pertanian, perhotelan, restoran, dan industri yang mengarah pada pengembangan ekonomi dengan menekankan pada pemanfaatan potensi lokal sekaligus berperan sebagai kawasan pusat pertumbuhan dan diharapkan dapat memberikan efek pembangunan bagi daerah sekitarnya.

Interaksi orang-orang Tionghoa dengan masyarakat pribumi Indonesia turut mempengaruhi budaya antar keduanya dan melahirkan kebudayaan baru yang menambah khazanah kebudayaan Indonesia. Sebagaimana diketahui bahwa tranformasi kebudayaan itu membawa pembaruan di segala bidang. (Supadjar, 2002)

Lasem telah mempresentasikan pluralisme multikulturalisme dalam kehidupan sosial masyarakatnya. Lasem, merupakan Kota Kecamatan yang memiliki keragaman etnik dan tumbuh dalam suasana saling mengakomodasi antar kebudayaan. Lasem merupakan refleksi perpaduan kebudayaan Arab, Thionghoa dan pribumi yang bisa selaras. Adanya gelombang budaya yang mewarnai kebudayaan dan kehidupan di Lasem. Hal itu disebabkan dalam rentang waktu tersebut terjadi gelombang migrasi dari etnis Tionghoa yang mendominasi perkembangan pusat-pusat perkotaan serta membentuk mayoritas penduduk perkotaan setelah bangsa Belanda di masa perdagangan dahulu kala (James C, 1975)

Lasem adalah kota yang didominasi oleh etnis Thionghoa sehingga kota ini sering dijuluki "Cina kecil". Namun, dominasi semacam itu telah membentuk harmoni saling menguntungkan dan saling membutuhkan antara Jawa dan Thionghoa abad yang lalu (Rizali, N. \& Bani Sudardi, 2015). Selain berkembang sebagai Kota Pecinan, ternyata Lasem juga tumbuh sebagai pusat jaringan penyebaran agama Islam dipesisir timur Pantai Utara Jawa.

Di sisi lain, Lasem juga menjadi basis ekonomi utama masyarakat Thionghoa di Rembang, seiring dengan migrasi orang-orang Thionghoa di Asia Tenggara. Menurut beberapa sumber lokal telah dilansir oleh beberapa media nasional, dikisahkan bahwa terdapat seorang Thionghoa Muslim bernama Bi Nang Un yang bermazhab Hanafi yang diutus oleh Dinasti Ming yang dipertahankan sampai sekarang, meskipun digunakan sebagai pondok pesantren dan kediaman para kyai.

Arsitektur pesisir dipandang sebagai konsep arsitektur yang merupakan relasi antara fungsi, bentuk dan makna arsitektur dari berbagai asal kebudayaan yang akhirnya mampu kesatuan yang utuh dalam membentuk identitas arsitektur kota pesisir, dengan ciri yang melekat sebagai bentuk akulturasi budaya dan memiliki nilai dan unsur yang adaptif terhadap segala perubahan.
Akulturasi itu sendiri merupakan suatu proses sosial yang timbul disaat suatu kelompok manusia dengan kebudayaan tertentu dihadapkan dengan unsur dari suatu kebudayaan asing. Kebudayaan asing tersebut lambat laun akhirnya dapat diterima dan diolah ke dalam kebudayaannya sendiri tanpa menyebabkan hilangnya unsur kebudayaan kelompok itu sendiri, secara damai dan serasi.

Fenomena akulturasi yang terjadi akibat dari peleburan berbagai macam budaya di kota-kota pesisir inilah, yang akhirnya melatar belakangi beberapa pihak yang akhirnya melakukan penelitian yang mengangkat topik akulturasi tersebut, di antaranya:

1. Machrus (2008). Simbol-simbol Sosial Kebudayaan Jawa, Hindu, dan Islam yang Dipresentasikan dalam Artefak Masjid Agung Surakarta. Tesis Program Pascasarjana UNS Surakarta.

2. Munawir Aziz (2014). Lasem Kota Tiongkok Kecil: Interaksi Thionghoa, Arab dan Jawa dalam Silang Budaya Pesisiran. Yogyakarta : Ombak

3. Ahmad Atabik (2016). Pencampuran Budaya Jawa dan Cina: Harmoni dan Toleransi Beragama Masyarakat Lasem. Semarang: Sabda.

4. Ir. Bachtiar Fauzy MT (2012), Konsep Kearifan Lokal Dalam Arsitektur Rumah Tinggal Masyarakat Kota Pesisir Utara Jawa. Kasus Studi: Arsitektur Rumah Tinggal di Kampung Sumber Girang - Lasem. Lembaga Penelitian dan Pengabdian Masyarakat. Universitas Katolik Parahyangan

Melihat Lasem di masa kini, menarik untuk melihat konfigurasi budaya yang membentuk Lasem, yakni budaya Jawa, Tionghoa, dan Arab. Akulturasi yang merupakan proses utama dari adaptasi budaya terhadap lingkungan dengan konsep difusi dikembangkan untuk merujuk perubahan yang dibawa melalui adaptasi, dengan atau tanpa kontak budaya. Kebanyakan budaya berkembang dengan meminjam (mengadaptasi) dari budaya lain.

Lasem tumbuh sebuah pusat permukiman orang Thionghoa yakni di daerah Dasun, Babagan dan Karangturi. Pecinan dengan segala atributnya mewarnai wajah arsitektur dan tradisi yang tampak di Lasem menjadikan daerah tersebut mendapat julukan "Tiongkok kecil". Bahkan di Lasem juga terdapat patung Buddha terbaring yang berlapis emas. Di samping itu Lasem juga menjadi salah satu simpul jaringan penyebaran agama Islam yang tampak dari kehadiran pesantren-pesantren. Pesantren-pesantren tersebut membawa adat tradisi yang memiliki unsur budaya Arab, seperti acara haul dan manakib. Selain itu juga ada Perkampungan Muslim di Soditan, sehingga tidaklah heran jika Lasem dikenal sebagai kota santri, dikarenakan banyaknya pesantren di daerah 
tersebut. Selain itu juga terdapat peninggalan bangunan Kolonial di sekitar Sungai Babagan.

Sejumlah literatur menunjukkan bahwa pada masa-masa awal kebangkitan Islam di pulau Jawa, banyak kriyawan kayu etnis Thionghoa Muslim yang berperan besar dalam pembangunan masjidmasjid, khususnya di pantai Utara Jawa Tengah (Graaf, 1997).

Pada umumnya, asumsi yang hidup di masyarakat adalah bahwa bentuk masjid-masjid itu berasal dari khazanah budaya Timur Tengah dan Gujarat-India (Graaf, 1997). Bentuk masjid abad ke-15 dan 16 merupakan metamorfosa dari bentuk masjid Jawa-Hindu/Budha ke bentuk masjid JawaIslam yang sangat boleh jadi karena adanya kontribusi kekriyaan kayu para pendatang etnis Thionghoa yang beragama Islam (Graaf, 1997). Bentuk bangunan masjidnya sangat khas dan tidak terdapat di belahan dunia yang lain. Orang-orang Thionghoa berdatangan ke Indonesia bukan hanya berdagang, namun seperti ketika mereka ke Arab, orang-orang Thionghoa yang datang ke Indonesia juga membawa "oleh-oleh" kebudayaan mereka, teknologi pembuatan kertas dan tinta serta ilmu cetak-mencetak ditambah ajaran Islam yang diperoleh dari Arab (Graaf, 1997).

Masuknya orang-orang Tionghoa di Nusantara menyebabkan terjadi interaksi dengan masyarakat pribumi. Di antara mereka ada yang menikah dengan wanita-wanita Indonesia dan saling bertukar kebudayaan. Di Pantai Utara Jawa itu di samping menyebarkan ajaran Islam juga budaya Thionghoa.

Interaksi para pendatang dengan masyarakat pribumi itulah yang akhirnya turut mempengaruhi budaya antar keduanya dan melahirkan kebudayaan baru yang menambah khazanah kebudayaan Indonesia.

Dari alasan bahwa bahasan mengenai akulturasi adalah hal yang cukup menarik dibahas, maka peneliti mengangkat tema akulturasi terutama di bidang arsitektur, menjadi tema besar dari penelitiannya, yaitu "Dinamika Akulturasi Arsitektur Thionghoa, Timur Tengah, Kolonial, dan Jawa, dengan mengambil studi lokasi di Lasem, Rembang, Jawa Tengah.

\section{Rumusan Masalah}

Bentuk dasar tampilan arsitektur pada bangunan-bangunan yang ada di Lasem yang diduga telah mengakulturisasi budaya setempat, nampaknya masih dapat ditelusuri sebagai bentuk dari ekspresi gaya Thionghoa yang berpadu dengan gaya Kolonial, Timur Tengah dan juga gaya arsitektur Jawa, sebagai gaya arsitektur lokal setempat. Dengan demikian, permasalahan yang akan diteliti untuk memastikan adanya dinamika akulturasi arsitektur di Lasem adalah sebagai berikut ini:

1. Apakah ada bagian-bagian bangunan, ornamen dan elemen dekoratif pada kawasan, mampu mengungkapkan ekspresi Thionghoa, Arab, Kolonial, dan Jawa yang ada di Kawasan Lasem?

2. Apakah ada kriteria tertentu dalam menggunakan bagian-bagian bangunan, ornamen dan elemen dekoratif yang memiliki ekspresi perpaduan (akulturasi) arsitektur Thionghoa (Cina), Timur Tengah (Arab), Kolonial, dan Jawa di Kawasan Lasem?

3. Bagaimanakah makna yang terdapat di balik penggunaan bagian-bagian bangunan, ornamen dan keindahan elemen dekoratif pada bangunan-bangunan yang ada di Kawasan Lasem?

\section{Metode Penelitian}

\section{Paradigma dan Metode}

Penelitian ini menggunakan model penelitian eksplorasi deskriptif melakukan pengamatan spasial dan visual arsitektural pada bangunan dan lingkungan hunian yang ada di Lasem. Penentuan unit-unit informasi dalam penelitian ini berbasis dari acuan teori yang berkaitan dengan tujuan penelitian berdasarkan hasil pengamatan di lapangan agar mendapat gambaran yang kontektual. Berikut ini beberapa kriteria dasar di dalam penggalian unit-unit informasi, antara lain yaitu;

1. Berdasarkan teori (theory based) dan ground riset dengan adanya catatan-catatan arsip historis dari hasil observasi data lapangan.

2. Mengandung pengertian yang jelas dan tegas, dengan model eksplorasi kawasan.

3. Bersifat operasional, sederhana, praktis, mudah dilaksanakan, dan mudah digunakan dalam pengolahan data dan analisis.

\section{Fokus Penelitian}

Peneliti melihat perpaduan dan akulturasi elemen-elemen arsitektural yang terjadi di Lasem dengan menggunakan pendekatan rasionalistik yang dilakukan berlandaskan pada pemahaman intelektual yang secara logik dan menekankan pada kemampuan konseptual teortitis dengan paradigma kualitatif yaitu dengan pengumpulan data berlangsung fleksibel berdasarkan rotasi data yang dilihat peneliti. Kajian data menggunakan kajian data verbal dan data visual dengan mencari esensi.

\section{Mekanisme Penelitian}

Survei lapangan dilakukan melalui observasi langsung kawasan permukiman multi-etnis Lasem. Survei lapangan dititikberatkan pada deskripsi data fisik beserta latar sosial, budaya, dan historisnya. Teknik pengamatan yang dilakukan berupa insight observation, diperkaya dengan interpretasi komparatif pada obyek-obyek yang dipilih sebagai kasus kajian.

Peneliti melakukan kegiatan obsevasi non partisipan memiliki kelebihan dari sudut pandang objektivitas, karena jauhnya peneliti dari fenomena topik yang diteliti mengurangi bias pengaruh penelti 
dari fenomena topik yang diteliti mengurangi bias pengaruh peneliti pada fenomena untuk mengetahui dan menganalisa pengaruh perkembangan di Kawasan Lasem terhadap akulturasi arsitektur yang terjadi, peneliti sebagai penonton atau penyaksi terhadap gejala atau kejadian yang menjadi topik penelitian.

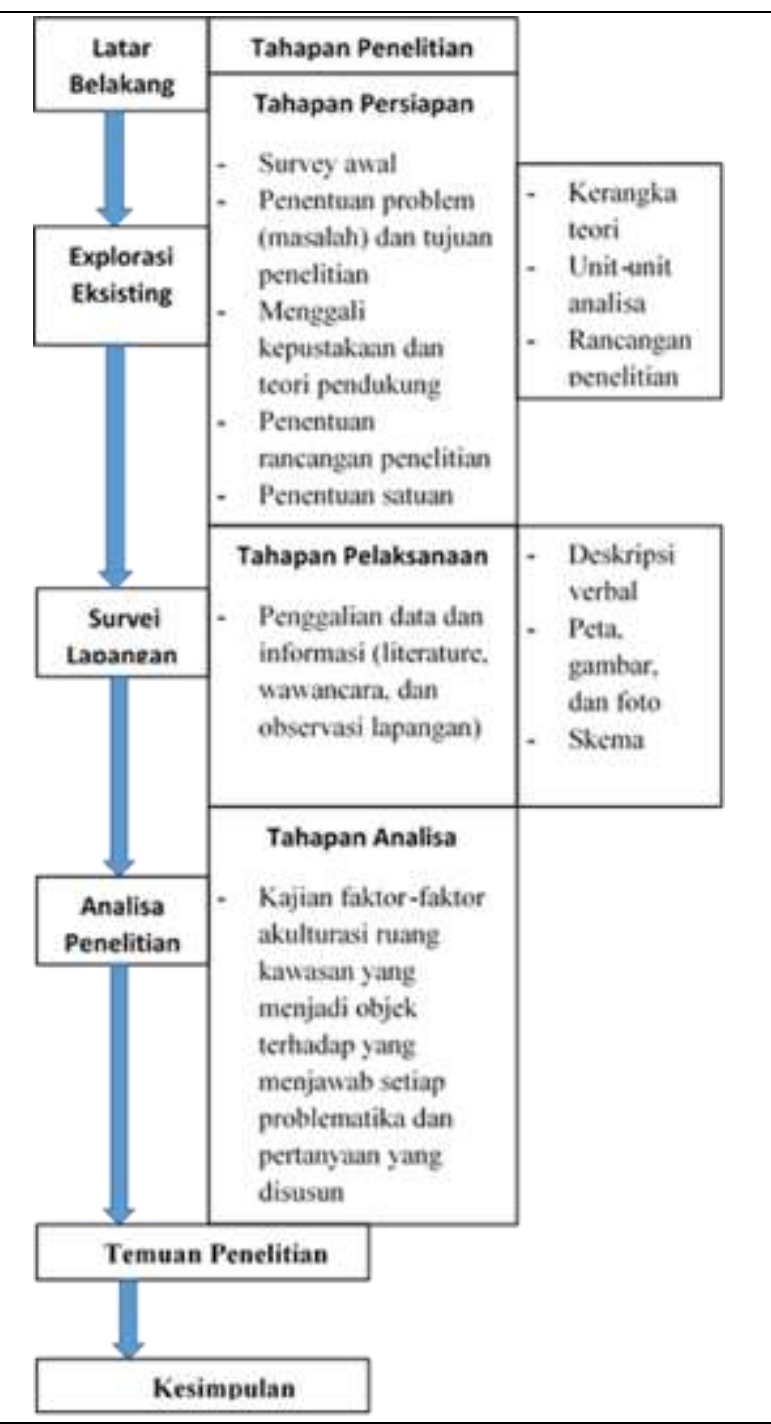

Gambar 3. Skema Langkah - Langkah Penelitian

\section{Objek Pengamatan}

Objek pengamatan meliputi bangunanbangunan rumah tinggal, lingkungan dan tapak dalam skala mikro, meso (kelompok rumah tinggal), serta makro untuk lingkup kawasan yang lebih luas yaitu kawasan permukiman multi-etnis di wilayah Kawasan Lasem.

Dalam penelitian ini, para peneliti memeriksa sebuah beberapa rumah di Lasem yang dipengaruhi oleh akulturasi dari Thionghoa, Timur Tengah, Jawa, dan Kolonial. Proses asimilasi dan akulturasi antara orang pendatang dengan penduduk setempat menghasilkan rumah-rumah yang memiliki tata letak ysng unik

Variabel penelitian digunakan untuk memberikan batasan terhadap elemen-elemen pembentuk kawasan yang diteliti menjadi obyek penelitian. Variabel-variabel tersebut ditentukan oleh temuan-temuan masalah yang terjadi di lapangan dan ditentukan juga oleh faktor-faktor mengapa hal itu terjadi, sehingga akan nampak bentuk akulturasi arsitektur yang menjadi temuan.

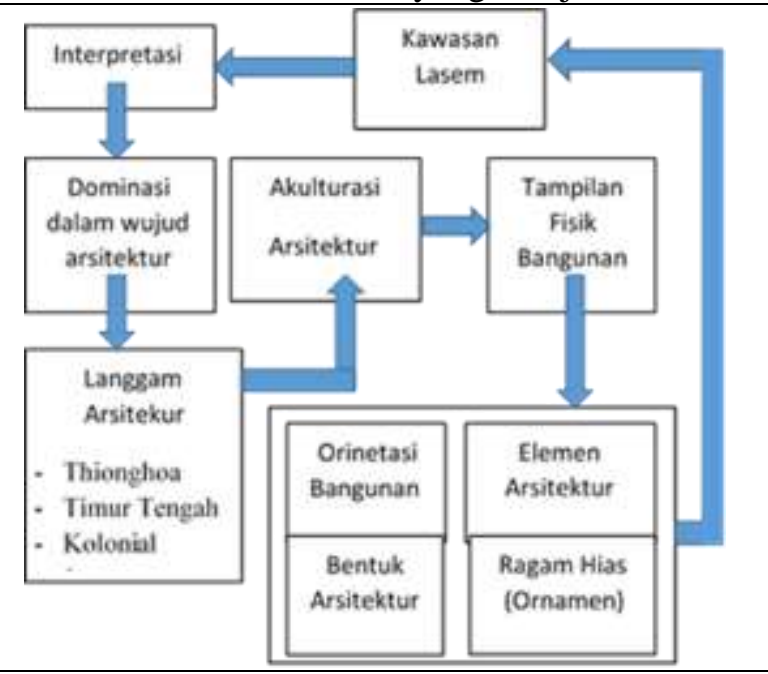

Gambar 4. Skema Variabel Penelitian

\section{Hasil Penelitian dan Pembahasan}

Daya tarik yang memanifestasi akulturasi dari kebudayaan masyarakat, termasuk di bidang arsitektur menjadi gambaran perkembangan ekspresi fisik dari sebuah etos komunitas.

Akulturasi budaya antaretnis di Indonesia telah terjadi sebagai akibat dari interaksi antara berbagai budaya pemukim atau imigran dan budaya Jawa lokal dengan semua karakteristik dan bentuknya yang berbeda (Widodo, S.T, 2015)

Arsitektur yang berkembang di Lasem mengalami perkembangan dari waktu ke waktu, yang merupakan hasil perpaduan antara arsitektur Cina Selatan (tempat asal sebagian besar orang Thionghoa yang ada di Lasem), arsitektur Jawa (Pesisiran dan Mataraman), arsitektur Kolonial Belanda, serta arsitektur Mediteran (yang pengaruhnya dibawa oleh pedagang-pedagang dari Timur Tengah).

Tulisan ini mencoba untuk melakukan ekplorasi dan dinamika akulturasi pada langgam dan bentuk-bentuk bangunan yang ada di Lasem. Bangunan-bangunan tersebut merupakan sebuah artefak budaya dari proses sejarah panjang Lasem yang dinamis, seperti tentang bagaimana pembauran tersebut dan bagaimana akulturasi tersebut tercermin dalam arsitektur.

Arsitektur Lasem berkembang sesuai dengan perubahan zaman yang terjadi. Perkembangan arsitektur sebelum penjajahan Belanda, berbeda dengan arsitektur pada waktu penjajahan.

Lasem adalah kota dengan sejarah yang sangat menarik. Meski merupakan kota kecil, Lasem menyimpan artefak historis yang terkait dengan proses akulturasi berbagai macam budaya dan membuktikan bahwa hubungan damai dan harmoni sejak berabad-abad yang lalu (Vlekke, 1959). Paling sedikit ada dua jenis peninggalan arsitektur yang ada di Lasem, yaitu tempat ibadah dan rumah tinggal. Bentuk rumah toko yang biasa sering terlihat di kota-kota besar, tidak terlihat di 
Lasem pada masa lalu. Ruko berkembang setelah zaman kemerdekaan sebagai akibat dari pengaruh telah mulai mahalnya harga tanah di Lasem, akibat prospek ekonomi Lasem yang menguntungkan dikarenakan merupakan jalur Jalan Pos yang menghubungkan Jakarta, Semarang, dan Surabaya. Berdasarkan variabel penelitian yang ditentukan sebelumnya yang dilihat dari tampilan fisiknya, maka akulturasi arsitektur dapat diamati dari empat aspek antara lain orientasi bangunan, bentuk arsitektur, elemen arsitektur, dan ragam hias (ornamen).

\section{Orientasi Bangunan}

Aspek fisik menilai suatu bentuk arsitektur dari suatu bangunan dapat dilihat dari orientasinya. Bangunan-bangunan rumah di Lasem kebanyakan berorientasi kepada Tuhan sebagai sang pencipta dengan perletakan yang hampir sama pada masingmasing rumah etnis yang ada di Lasem.

Tabel 1. Perbandingan Orientasi Bangunan

Thionghoa, Timur Tengah, Kolonial, dan Jawa

1. Arsitektur Thionghoa

Terdapat ruang sakral yang digunakan sebagai ruang tempat penyimpanan altar leluhur.

2. Arsitektur Timur Tengah

Terdapat ruang khusus untuk sembhayang (musholla). Pada pelataran atau halaman depan sebelah kanan dan kirinya ada peninggian area, area tersebut kemungkinan digunakan apabila ada acara keagamaan, sebagai pemisah area pria dan wanita, serta pada bagian tengahnya merupakan area netral.

3. Arsitektur Kolonial

Tidak ada ruang sakral pada bangunan kolonial di Lasem.

4. Arsitektur Jawa

Pada bangunan Jawa di Lasem, tidak terdapat senthong tengah. Penghilangan senthong tengah ini diakibatkan perbedaan mata pencaharian. Masyarakat Jawa pedalaman yang merupakan petani memanfaatkan senthong tengah sebagai tempat menyimpan padi (penghormatan terhadap Dewi Sri). Tetapi bagi masyarakat Jawa pesisir yang berprofesi sebagai nelayan dan pedagang, senthong tengah tidak lagi memiliki fungsi.

\section{Bentuk arsitektur}

Tata letak bangunan di Lasem telah nampak adanya proses akulturasi masyarakat. Sebenarnya, Akulturasi adalah bentuk asimilasi antara dua budaya atau lebih yang bersinergi untuk membentuk jembatan antara karakter dari dua budaya yang berbeda atau beberapa budaya (Eagleton, 2000).

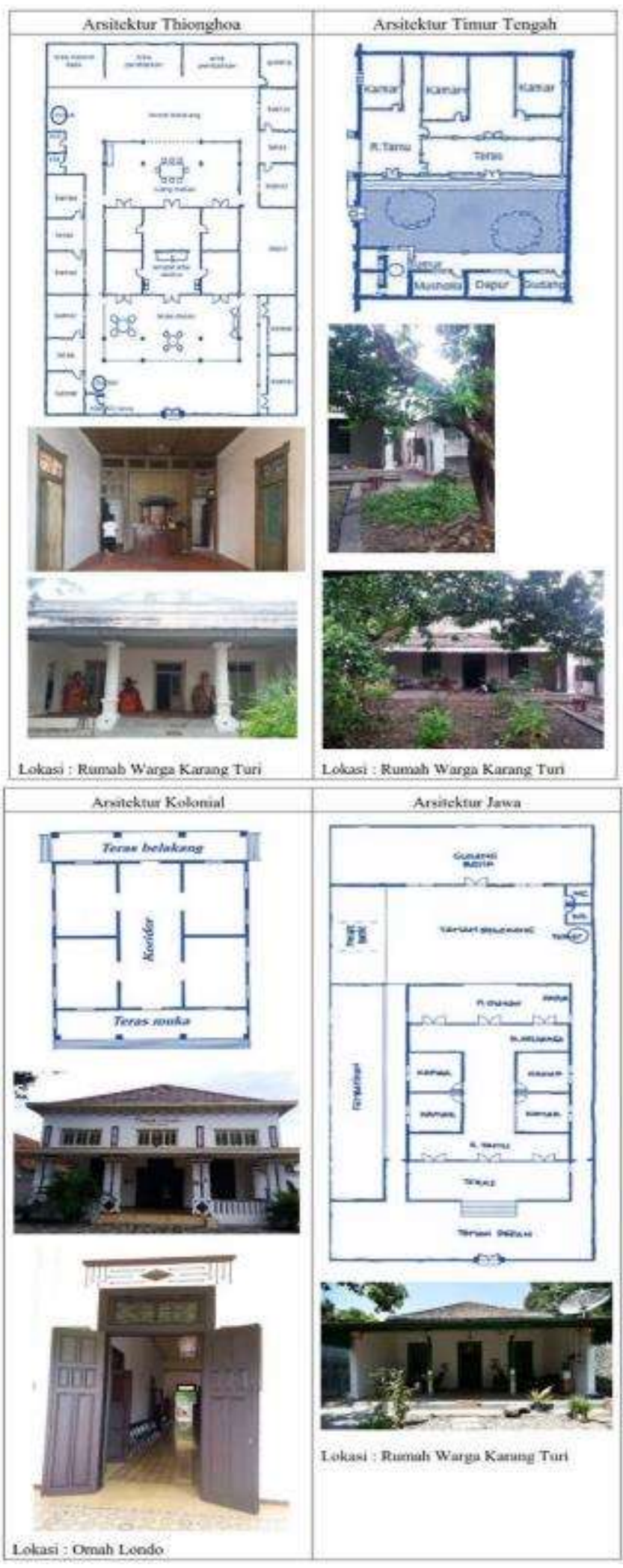

Gambar 5. Orientasi Bangunan

Beberapa bangunan memiliki prinsip tata letak yang sama, tetapi massa bangunan pola masih mengikuti arsitektur asalnya. Proses akulturasi diekspresikan melalui desain bangunan utama.

Tabel 2. Perbandingan Bentuk Arsitektur Thionghoa, Timur Tengah, Kolonial, dan Jawa 
1. Arsitektur Thionghoa

Pembentukan ruang didasarkan pada konsep jian, yaitu suatu ruang persegi empat yang dibatasi oleh dinding atau kolom yang merupakan satu modul struktur dan berfungsi sebagai pembatas ruang.

\section{Arsitektur Timur Tengah}

Bentuk pagar depan yang tinggi terbuat dari tembok, serta berpintu gerbang. Hal ini menjadi alasan supaya orang luar tidak dapat melihat ke dalam rumah dan pada area tersebut penghuni wanita dapat melepaskan jilbab mereka. Bagian plafond menggunakan konstruksi dari kayu.

3. Arsitektur Kolonial

Rumah kolonial terlihat tidak mempunyai pengembangan ke arah belakang. Biasanya menggunakan bidang dinding selain pembatas ruang juga sebagai struktur yang menahan atap (dinding pemikul). Karena fungsinya menahan beban maka secara otomatis dimensinya pun akan lebih besar dari dinding pada umumnya. Material yang umum digunakan pada dinding seperti ini adalah pasangan bata yang disusun satu batu penuh sehingga dimensinya lebih tebal.

\section{Arsitektur Jawa}

Pada bangunan Jawa di Lasem, tidak terdapat senthong tengah. Penghilangan senthong tengah ini diakibatkan perbedaan mata pencaharian. Masyarakat Jawa pedalaman yang merupakan petani memanfaatkan senthong tengah sebagai tempat menyimpan padi (penghormatan terhadap Dewi Sri). Tetapi bagi masyarakat Jawa pesisir yang berprofesi sebagai nelayan dan pedagang, senthong tengah tidak lagi memiliki fungsi.

\section{Elemen Arsitektur}

Elemen-elemen arsitektur rumah-rumah di Lasem banyak yang telah mengalami perpaduan kebudayaan dengan budaya Jawa sebagai budaya asli daerah setempat. Rumah-rumah di Lasem kebanyakan memiliki teras yang luas untuk mereka bersosialisasi orang-orang di lingkungan itu. Sedangkan adanya halaman yang luas, biasanya digunakan untuk bersantai di sore hari. Selain itu bukaan jendela yang besar-besar dengan tiang-tiang yang sarat denga elemen dekoratif juga menjadi ciri percampuran langgam arsitektur Thionghoa, Timur Tengah, Kolonial, dan Jawa.

Tabel 3. Perbandingan Elemen Arsitektur Thionghoa, Timur Tengah, Kolonial, dan Jawa
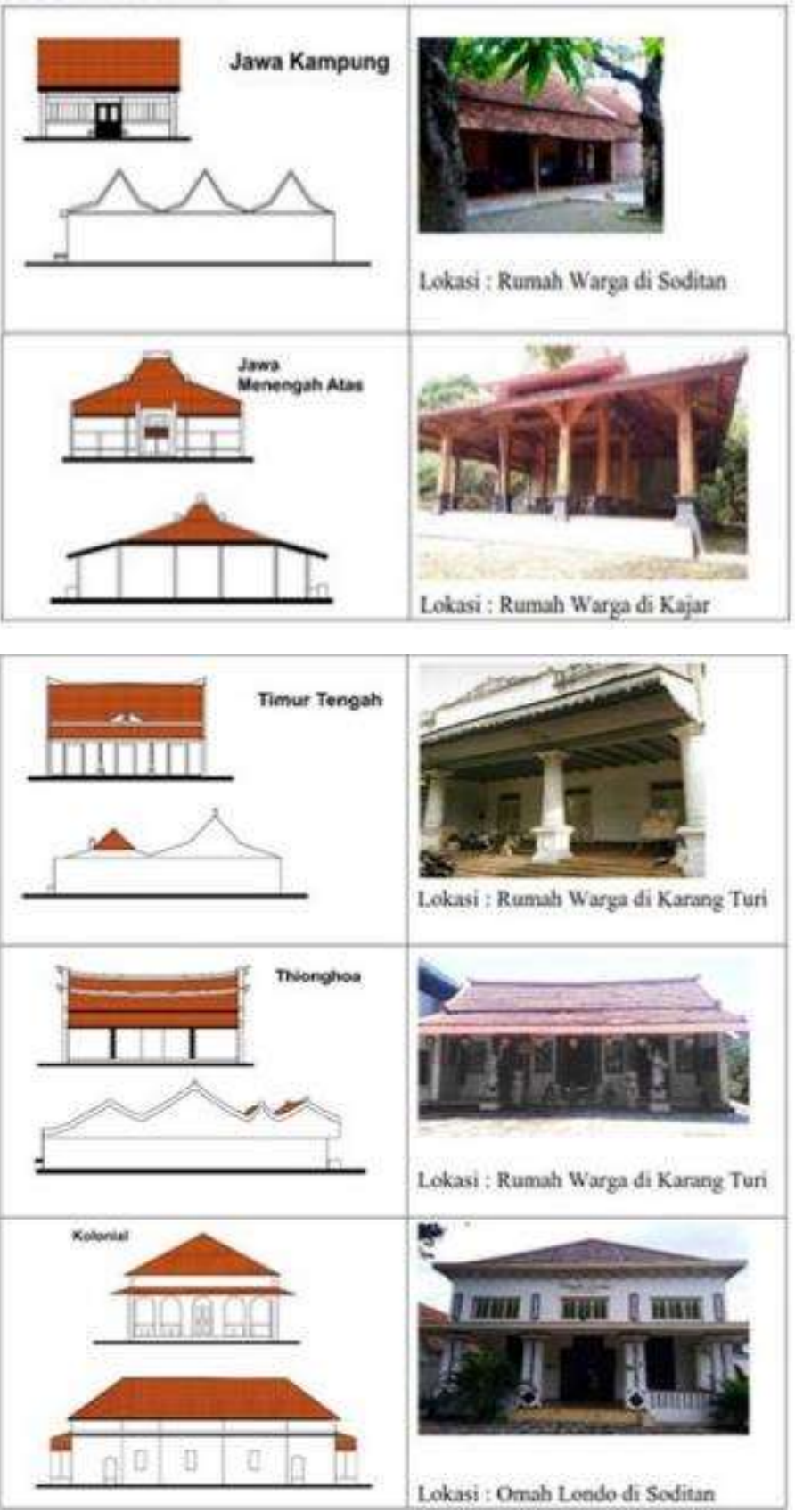

Gambar 6. Perbandingan Bentuk Arsitektur Jawa Kampung dan Jawa Menengah, Thionghoa, Timur Tengah, dan Kolonial

\begin{tabular}{|l|}
\hline 1. Arsitektur Thionghoa \\
\hline Terdapat Courtyard yang merupakan ruang \\
terbuka pada rumah Tionghoa. Ruang terbuka \\
ini sifatnya lebih privat. Biasanya digabung \\
dengan kebun/taman. \\
Rumah-rumah gaya Tiongkok Utara sering \\
terdapat courtyard yang luas dan kadang- \\
kadang lebih dari satu, dengan suasana yang \\
romantis. Di daerah Tiongkok Selatan tempat \\
banyak orang Tionghoa Indonesia berasal, \\
courtyard-nya lebih sempit karena lebar \\
kapling rumahnya tidak terlalu besar
\end{tabular}




\begin{tabular}{|c|c|}
\hline & $\begin{array}{l}\text { Ruang yang memisahkan laki-laki dan } \\
\text { perempuan sangat kental terasa, yaitu } \\
\text { penerapannya secara ruang dapat kita lihat } \\
\text { dari pembagian ruang publik dan sekunder. } \\
\text { Jalur primer dangan pintu masuk pada bagian } \\
\text { belakang dengan norma budaya timur tengah } \\
\text { yang menghormati wanita agar tidak bertemu } \\
\text { laki-laki yang bukan muhrimnya. Pembatasan } \\
\text { antara ruang publik dan privat ini dibatasi oleh } \\
\text { tabir berupa tembok, bilik atau korden. }\end{array}$ \\
\hline & \\
\hline & $\begin{array}{l}\text { Bentuk arsitekturnya disesuaikan dengan } \\
\text { kondisi tropis dan lingkungan budaya. } \\
\text { Elemen dekoratif manusia yang tidak } \\
\text { proporsional seperti pada elemen dekoratif } \\
\text { pada biasanya bangunan Belanda. } \\
\text { Penggunaan material dan konstruksi modern, } \\
\text { elemen estetis, serta bentuk pintu dan jumlah } \\
\text { bukaan jendela yang mengadaptasi iklim } \\
\text { setempat terhadap bangunan }\end{array}$ \\
\hline \multicolumn{2}{|r|}{ Arsitektur Jawa } \\
\hline & $\begin{array}{l}\text { Terdapat kolom berbentuk segi empat } \\
\text { (sokorawa) dan kolom berbentuk silinder } \\
\text { (sokoguru) ditinjau berdasarkan aspek } \\
\text { simbolik yang melambangkan tentang nilai } \\
\text { ajaran Sholat pada agama Islam. Bila ditinjau } \\
\text { dari aspek konstruksi, tiang-tiang yang ada } \\
\text { pada memiliki sisi kekuatan simetris yang } \\
\text { bersatu dengan kolom yang sejajar diantara } \\
\text { kolom satu dengan yang lain dengan fungsi } \\
\text { yang sama walaupun mempunyai bentuk yang } \\
\text { berbeda. Sokorawa dan sokoguru merupakan } \\
\text { kepercayaan pra Islam (lingga dan yoni) yang } \\
\text { kemudian telah diadaptasikan ke dalam ajaran } \\
\text { Islam. }\end{array}$ \\
\hline
\end{tabular}

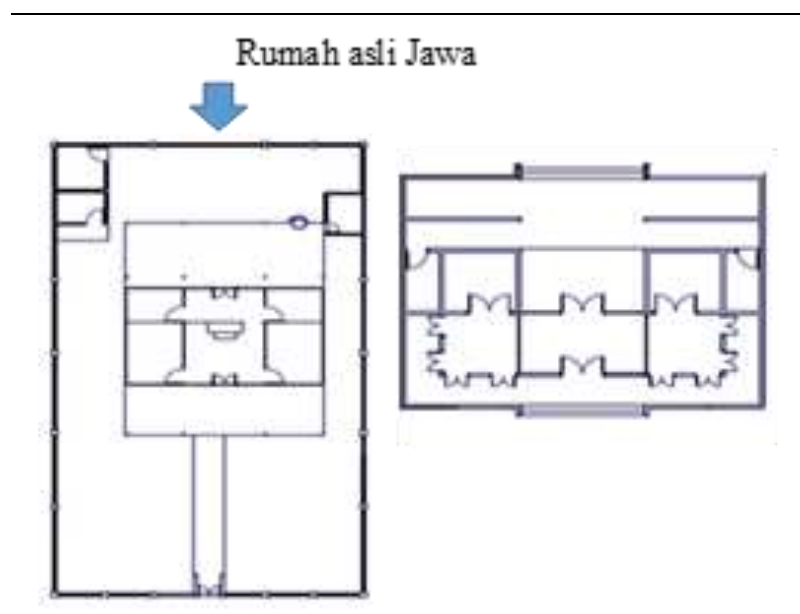

Rumah yang sudah mengalami akulturasi kebudayaan dan arsitektur

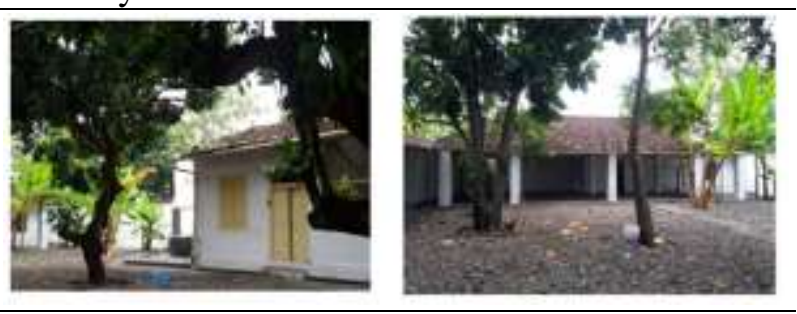

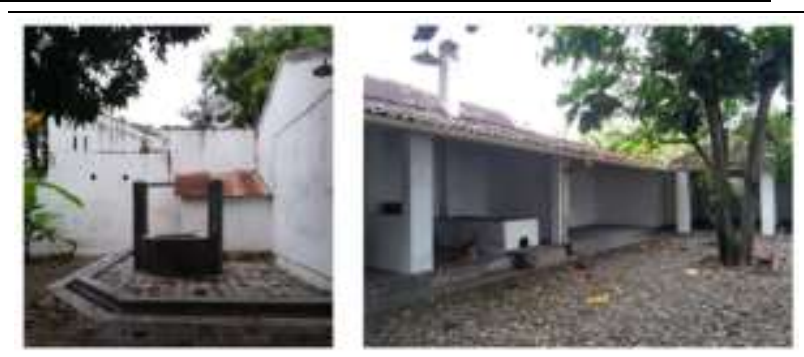

Gambar 7. Courtyard pada Rumah di Lasem yang Sudah Mengalami Akulturasi

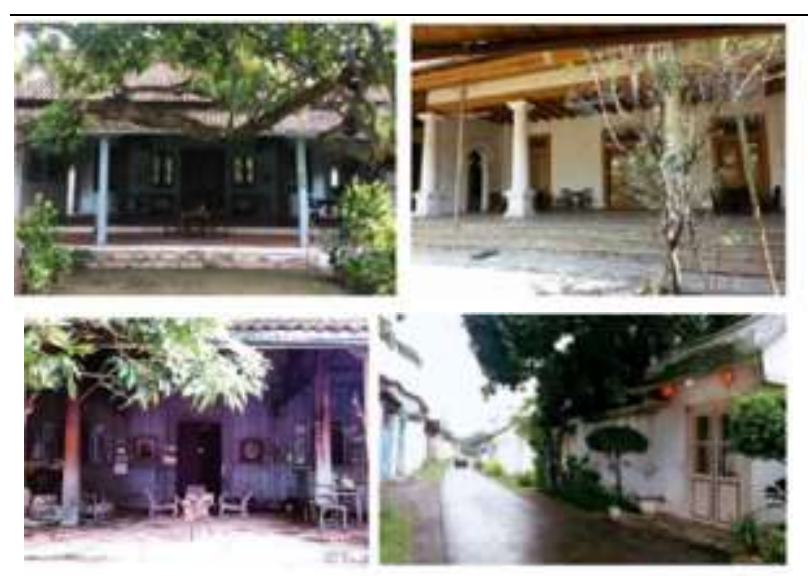

Gambar 8. Elemen Arsitektur pada Rumah dan Ruang Jalan Kampung

\section{Ragam Hias}

Ragam hias atau ornament yang digunakan sebagai elemen interior dan juga sebagai elemen estetis interior mengalami pencampuran budaya Thionghoa, Timur Tengah, Kolonial, dan Jawa. Ornamen banyak ditemukan pada bovenlicht di atas bukaan pintu atau jendela interior terdapat ornamen yang mengalami pencampuran.

Tabel 4. Perbandingan Ragam Hias Arsitektur Arsitektur Thionghoa, Timur Tengah, Kolonial dan Jawa

\begin{tabular}{|l|l|}
\hline 1. Arsitektur Thionghoa \\
\hline & $\begin{array}{l}\text { Menggunakan dua jenis ragam hias (pattern) } \\
\text { yaitu: key pattern dan diaper pattern. Key } \\
\text { pattern merupakan ragam hias yang } \\
\text { digandakan secara linear saja dan membentuk } \\
\text { sebuah sabuk ornament. Sedangkan diaper } \\
\text { pattern merupakan ragam hias yang } \\
\text { digandakan untuk mengisi bidang-bidang. }\end{array}$ \\
$\begin{array}{l}\text { Kebanyakan atap rumahnya merupakan atap } \\
\text { renzi / gable roof dari Cina daratan yang } \\
\text { merupakan atap berbentuk pelana dengan } \\
\text { dinding ampig di tepi-tepinya. Atap seperti ini } \\
\text { memang umum digunakan untuk fungsi rumah } \\
\text { tinggal. }\end{array}$ \\
\hline 2.
\end{tabular}


RR. Sophia Ratna Haryati

Secara umum, fisik bangunan masih mempertahankan pola denah ruang yang simetris dengan konstruksi langit-langit serta penggunaan ornament dan lambing-lambang kepercayaan Thionghoa.

Untuk rumah tinggal tanpa batas kapling dengan atap perisai dengan patahan (gunungan). Sedangkan untuk rumah tunggal berkapling yang disekelilingi tembok (pager bumi) dan rumah tunggal tanpa batasan kapling. Rumah tunggal berkapling beratap perisai yang berderet dengan gunungan berjumlah genap (biasanya 4 gunungan).

\section{Arsitektur Kolonial}

Pattern yang digunakan cenderung lebih menggunakan perpaduan dari unsur bidang, garis, atau makhluk hidup seperti hewan atau tumbuhan sebagai pola dalam ornamennya. Hal ini dipengaruhi oleh gaya art deco dan art nouvo yang ketal dari Eropa pada pola desainnya.

Pengaruh budaya Barat nampak pada pilar-pilar besar yang mengingatkan pada gaya bangunan Parthenon dari zaman Yunani dan Romawi. Lampu-lampu gantung dari Italia dipasang pada serambi depan. Antara jendela dan pintu dipasang cermin besar dengan gantungan porselen.

\section{Arsitektur Jawa}

Adanya ornamen yang memiliki motif keseimbangan (cakrabyuha) yang merupakan motif dari Majapahit (Hindu).

Struktur atap yang digunakan adalah atap limasan yang lebih kompleks daripada atap kampong yang mencakup teknik yang lebih canggih, lebih banyak material yang terpakai. Penghuni biasanya memiliki kelas status sosial atau ekonomi yang lebih tinggi dari penghuni atap kampung biasa.

\section{Kesimpulan}

Proses akulturas arsitektur telah menciptakan suatu pembauran kebudayaan yang terjadi di Lasem selama berabad-abad antara budaya Thionghoa, Timur Tengah, Kolonial, dan Jawa telah menghasilkan sebuah pola bentuk bangunan yang sedikit demi sedikit mulai nampak berpengaruh pada pola perancangan bangunan hunian.

Akulturasi telah dilakukan oleh masyarakat Lasem, tidak hanya dalam budaya tetapi juga dalam bentuk arsitektur, spasial pola dan detail bangunan. Akulturasi ini menghilangkan perbedaan antara komunits. Akulturasi juga menghasilkan keragaman arsitektur yang khas di Lasem. Keserasian dalam masyarakat memungkinkan akulturasi dan asimilasi berlangsung dengan damai dan tercermin tidak hanya kehidupan sosial warga Lasem tetapi juga desain arsitektur.
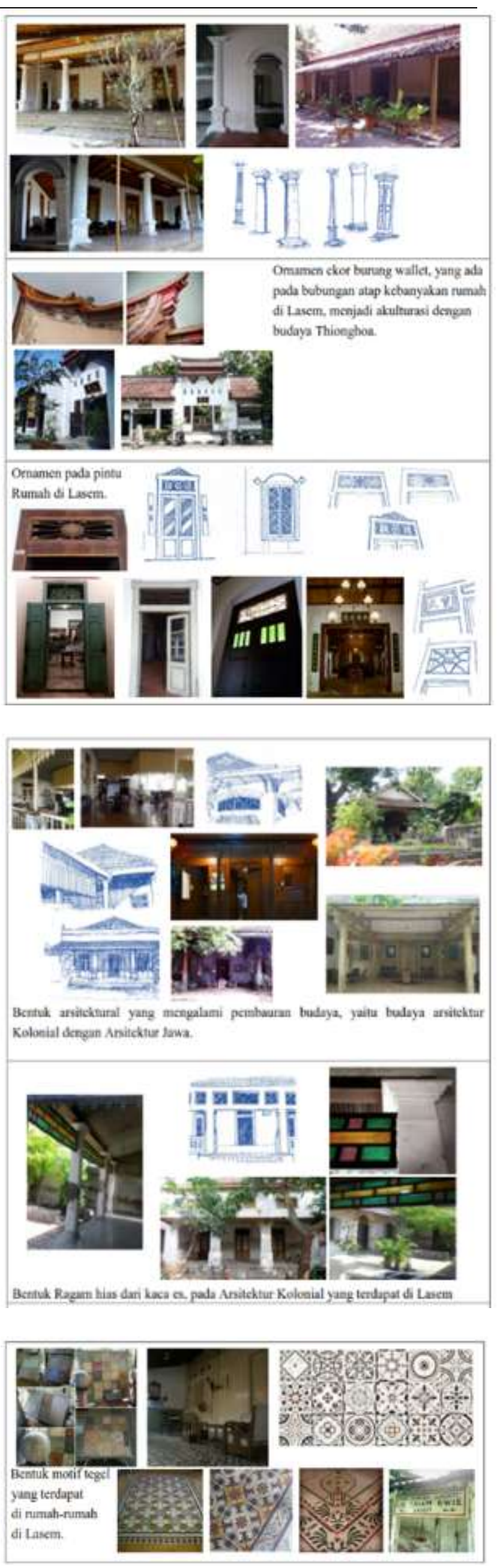

Gambar 9. Ragam Hias Arsitektural 
Akulturasi dan asimilasi antara pendatang dari Cina, Arab, dan Kolonial dengan penduduk asli di Lasem yang merupakan orang Jawa, telah mempengaruhi tata ruang dan detail bangunan di Lasem dan dibuat baru dirancang dan bentuk arsitektur yang unik.

Ragam akulturasi arsitektur yang ada menggambarkan percampuran dari langgam arsitektur yang terekspresi melalui pelingkup bangunan, yakni: pada bagian kepala (atap), badan (dinding) dan kaki (lantai/alas) bangunan beserta ruang yang dibentuknya secara berkesinambungan dan berkaitan antara satu dengan lainnya. Ragam akulturasi arsitektur ini pada akhirnya menampilkan keindahan berdasarkan susunan pelingkupnya.

Perbedaan yang tampak secara visual pada bentuk atap dan konstruksi pada tipe hunian di Lasem, yaitu hunian bergaya Thionghoa, Timur Tengah, Kolonial, dan Jawa yang merupakan representasi dari status sosial penghuninya yang bersilangan dengan identitas antar etnis dan sekaligus juga identitas dalam etnisnya sendiri yang dipengaruhi oleh ekonomi dan politik yang terjadi pada masyarakat Lasem sepanjang sejarah.

Susunan ruang dan elemen pelingkup bangunan di Lasem memiliki kesamaan dengan pola bangunan arsitektur Kolonial, yakni: susunan ruang yang berbentuk simetri dan ruang terbagi menjadi empat area, yakni area teras, ruang tamu/keluarga, ruang tidur dan ruang servis atau dapur.

Susunan ini memberikan kesan formal pada gubahan dan pembagian ruangnya, sehingga susunan ruang tersebut juga menyiratkan pada rumah di Lasem yang terdiri dari: bagian depan, tengah/utama dan belakang, susunan ini menyiratkan ragam akulturasi arsitektur melalui gubahan ruang dan susunan elemen pelingkupnya.

Dalam melihat dan menelaah akulturasi arsitektur, tulisan ini tidak berambisi untuk mencari asal mula (origin) atau melihat siapa terpengaruh siapa, tetapi lebih pada pemahaman arsitektur sebagai sebuah proses yang terjadi akibat adanya pertemuan budaya yang menjadi khas dan bermakna bagi masyarakat Lasem.

Temuan penelitian menunjukkan bahwa proses akulturasi sangat mempengaruhi struktur bangunan di Lasem. Banyak bangunan di Lasem memadukan arsitektur Thionghoa, Timur Tengah, Jawa, dan Kolonial dalam tata ruangnya dan rincian. Hasil dari penelitian ini adalah model proses akulturasi yang tercermin dalam arsitektur.

\section{Daftar Pustaka}

Eagleton, T. 2000. The idea of culture. Malden, MA: Blackwell Publisher Ltd.

Graaf H.J. De \& Th Pigeaud. 1997. “Cina Muslim Di Jawa Abad XV dan XVI Antara Historis dan Mitos (terjemahan dari: Chinese Muslim In Java in The 15th and 16th Centuries: The
Malay Annals Of Semarang And Cerbon)". Yogyakarta: PT.Tiara Wacana.

James C, Jackson. 1975. "The China Town of Southeast Asia: Traditional Component of City's Central Asia”. Dalam Pasific Viewpoint. Volume 16 No.1.

Rizali, N. \& Bani Sudardi. 2015Social Relation Between Javanese And Chinese Community In Batik Processing In Lasem

Csentral Java, Journal of Education and Social Sciences, Vol. 5, issue 2, (October), pp 166169,

Supadjar, Damardjati, Dr., Nawang Sari. 2002. "Butir-butir Renungan Agama, Spritualitas, dan Budaya". Yogyakarta: Fajar Pustaka Baru

Widodo, S.T., Interethnic Acculturation in Java: The Names of Chinese People in Lasem on the North Coast of Java, Asian Journal of Social Sciences \& Humanities Vol. 4 no.4, pp 8-15, November 2015

Vlekke, Bernard H.M., 1959. Nusantara: A History of Indonesia, N.V. Vitgeverij W. van HoeveS. Gravenhage, Brussel. 